\title{
HUBUNGAN PENGUASAAN UNSUR INTRINSIK CERPEN \\ DENGAN KEMAMPUAN MENULIS CERPEN SISWA \\ KELAS XI SMK SWASTA MAJU BINJAI \\ TAHUN PELAJARAN 2019/2020
}

\author{
Kharisma Ahmad ${ }^{1}$ \\ Sri Ulina Br Ginting ${ }^{2}$ \\ M.Ali Sidiqin ${ }^{3}$
}

\begin{abstract}
ABSTRAK
Penelitian ini bertujuan untuk mengetahui Hubungan penguasaan unsur intrinsik cerpen dengan kemampuan menulis cerpen siswa kelas XI SMK Swasta Maju Binjai Tahun Pelajaran 2019/2020. Populasi penelitian ini seluruh siswa kelas kelas XI SMK Swasta Maju Binjai yang berjumlah 86 orang dengan sampel 24. Metode penelitian yang digunakan adalah metode deskriptif korelasional. Alat pengumpulan data pada penelitian ini berupa tes objektif pilihan berganda untuk unsur intrinsik cerpen dan untuk kemampuan menulis cerpen berupa tes uraian. Setelah dianalisis, diketahui bahwa nilai yang diperoleh siswa dalam tes penguasaan unsur intrinsik cerpen dalam katagori baik dengan nilai rata-rata siswa 81 sedangkan nilai kemampuan menulis cerpen siswa berada dalam katagori baik dengan nilai rata-rata siswa 71 . Sedangkan hubungan $\left(\mathrm{r}_{\mathrm{xy}}\right)$ diperoleh sebesar 0,86 Setelah dikonsultasikan dengan r.tabel tingkat kepercayaan 95\% diketahui $r$. hitung $(0,86)>$ r. tabel $(0,279)$. Berdasarkan hasil penelitian maka hipotesis yang berbunyi "Ada hubungan penguasaan unsur intrinsik cerpen dengan kemampuan menulis cerpen siswa kelas XI SMK Swasta Maju Binjai Tahun Pelajaran 2019/2020”diterima.
\end{abstract}

Kata kunci : unsur intrinsic cerpen, kemampuan menulis cerpen 


\section{Pendahuluan}

\subsection{Latar Belakang}

Sastra disebut juga peristiwa komunikasi. Di dalam peristiwa sastra, pendengar atau pembaca menemukan kepuasaan kalau ia menyadari bahwa telah banyak memahami dan merasakan pikiran-pikiran dan perasaanperasaan penulis. Demikian pula sebaliknya seorang penulis mendapat kepuasan seandainya dia tahu bahwa pikiran-pikiran dan perasaanperasaan yang disampaikan melalui karyanya dapat diterima dengan oleh pendengar dan pembacanya. Akan tetapi, komunikasi dalam peristiwa sastra memiliki hal-hal khusus. Tidaklah cukup bagi seorang pendengar atau pembaca untuk hanya memahami dan merasakan isi hati penulis. Pendengar atau pembaca itu harus sadar akan nilai-nilai lain, yang terkandung dalam karya sastra itu disamping pengalaman biasa.

Adapun nilai-nilai ini berhubungan dengan cara atau bentuk bagaimana penulis menyampaikan pengalaman yang bernilai sastra itu. Dengan kata lain, seorang pendengar atau pembaca sastra seharusnya tidak hanya memusatkan perhatian kepada apa yang disampaikan oleh penulis, akan tetapi seorang pendengar sastra atau pembaca sastra harus juga memperhatikan cara atau bentuk isi hati yang disampaikan penulis. Justru disinilah letak kekhasan karya sastra sebagai alat komunikasi. Nilainya sebagai karya sastra tidak hanya terletak pada apa yang disampaikannya, akan tetapi juga pada cara atau bentuk penyampaian. Dengan demikian kepuasan yang didapat seyogyanya tidak hanya karena pendengar atau pembaca dapat menerima isi hati penulis, akan tetapi juga karena ia dapat memahami dan menghargai penguasaan penulis terhadap cara atau bentuk penyampaian yang dipergunakannya sebagai bentuk komunikasi. Sastra tidak hanya memberikan kepuasan nilai-nilai pengalaman biasa yaitu dalam bentuk gagasan-gagasan dan perasaanperasaan, akan tetapi juga nilai-nilai seni, dalam bentuk kepuasan karena pendengar atau pembaca memahami dan mengagumi penguasaan penulis atas berbagai cara sehingga ia dapat menyampaikan isi hatinya dengan sempurna.

Sumarjo mengatakan :"Bahwa dengan membaca karya sastra, pembaca dapat mengetahui kebenaran hidup, pembaca mendapatkan sesuatu kegembiraan dan kepuasan batin sehingga kebutuhan terhadap naluri keindahan terpenuhi, serta menolong pembaca menjadi manusia yang berbudaya"

Untuk memahami dan menikmati karya sastra diperlukan pemahaman tentang teori sastra. Teori sastra merupakan ilmu yang menyelidiki secara mendalam tentang asas-asas sastra, hakikat sastra, gaya, susunan dan jenre sastra. Teori sastra menjelaskan kepada kita tentang konsep sastra sebagai salah satu disiplin ilmu humaniora yang akan mengantarkan kita ke arah pemahaman dan penikmatan fenomena yang terkandung di dalamnya. Dengan mempelajari teori sastra, kita akan memahami fenomena kehidupan manusia yang tertuang di dalam teori sastra. Sebaliknya juga, dengan memahami fenomena kehidupan manusia dalam teori sastra kita akan memahami pula teori sastra.

Cerpen merupakan salah satu bentuk karya sastra yang diakui keberadaannya disamping novel, puisi dan drama yang masuk ke dalam materi pembelajaran sastra di lingkungan sekolah. Cerpen adalah kisahan pendek (kurang dari 10.000 kata) memberikan kesan tunggal yang dominan dan memusatkan diri pada satu tokoh dalam satu situasi. Pengajaran sastra di lingkungan sekolah berfungsi sebagai sumber pengetahuan, membina sikap kreatif, membina kepekaan emosional dan membina kemampuan bernalar 
siswa. Pengajaran sastra itu bertujuan untuk meningkatkan kemampuan siswa dalam menulis karya sastra. Untuk menulis sebuah karya sastra siswa terlebih dahulu diajarkan mengenai langkah -langkah menulis sebuah karya sastra dalam hal ini adalah cerpen.

Pembelajaran Bahasa dan Sastra Indonesia bertujuan mengarahkan siswa agar mampu meningkatkan kemampuan untuk berkomunikasi dalam bahasa Indonesia dengan baik dan benar, baik secara lisan maupun tertulis. Pembelajaran bahasa dan sastra Indonesia memiliki empat aspek kebahasaan, yakni keterampilan menyimak, keterampilan berbicara, keterampilan membaca, dan keterampilan menulis. Salah satu kompetensi yang harus dicapai siswa dalam pembelajaran bahasa dan sastra Indonesia adalah kemampuan menulis.

Kemampuan menulis merupakan keterampilan yang sangat penting dalam kehidupan, tidak hanya penting dalam kehidupan pendidikan, tetapi juga sangat penting dalam kehidupan masyarakat. Kemampuan menulis adalah kemampuan seseorang untuk menuangkan buah pikiran, ide, gagasan, dengan mempergunakan rangkaian bahasa tulis yang baik dan benar.

Berdasarkan observasi yang dilakukan di SMK Swasta Maju Binjai dalam pembelajaran Bahasa Indonesia khususnya menulis cerpen tergolong kurang. Dari hasil wawancara yang dilakukan peneliti dengan guru Bahasa Indonesia yang mengajar di SMK Swasta Maju Binjai, menyatakan kurangnya minat siswa dalam menulis cerpen. Hal tersebut terjadi karena kurangnya penguasaan siswa tentang teori sastra yaitu unsur intrinsik cerpen. Karena para siswa kurang memahami tentang unsur intrinsik cerpen membuat mereka kurang mampu menulis cerpen dengan benar.
Kemudian, beberapa penelitian yang relevan juga dilakukan sebelumnya mengenai kemampuan penguasaan unsur intrinsik cerpen dengan kemampuan menulis cerpen seperti : Penelitian yang dilakukan Riski Puspita Sari, Martono, Agus Wartiningsih yang berjudul Kemampuan mengidentifikasi unsur Intrinsik Cerpen Siswa Kelas XI SMA Negeri 1 Semparuk. Penelitian yang berjudul Korelasi Antara Kebiasaan Membaca Cerita dan Pemahaman Unsur Intrinsik Cerpen dengan Kemampuan Menulis Cerpen Siswa Kelas X SMA Negeri Sekabupaten Boyolali. Penelitian Ryan Mahendra berjudul "Kemampuan Menulis Cerita Pendek Siswa Kelas XI SMA Negeri 1 Raman Utara Tahun Pelajaran 2016/2017.

Berdasarkan latar belakang masalah tersebut, maka peneliti ingin mengangkat masalah ini menjadi salah satu penelitian yang berjudul "Hubungan Penguasaan Unsur Intrinsik Cerpen Dengan Kemampuan Menulis Cerpen Siswa Kelas XI SMK Swasta Maju Binjai Tahun Pelajaran 2019/ 2020.

\subsection{Identifikasi Masalah}

Adapun identifikasi masalah tersebut adalah :

1. Kurangnya penguasan siswa tentang unsur intrinsik cerpen.

2. Kurangnya kemampuan siswa dalam menulis cerpen

\subsection{Batasan Masalah}

Pembatasan masalah ini gunanya untuk mempertujuan konsep. Maka peneliti membatasi masalah ini pada hubungan penguasaan unsur intrinsik cerpen dengan kemampuan menulis cerpen oleh siswa kelas XI SMK Swasta Maju Binjai Tahun Pelajaran 2019/ 2020. 


\subsection{Rumusan Masalah}

Rumusan masalah merupakan kelanjutan uraian pendahuluan. Dalam rumusan masalah penulis membuat rumusan spesifikasi terhadap hakikat masalah yang diteliti. Dengan demikian rumusan masalah pada penelitian ini adalah Seberapa besar hubungan penguasaan unsur intrinsik cerpen dengan kemampuan menulis cerpen oleh siswa kelas XI SMK Swasta Maju Binjai Tahun Pelajaran 2019/ 2020 ?

\subsection{Tujuan Penelitian}

Tujuan penelitian adalah merupakan hal yang sangat penting dalam menyusun rencana penelitian. Tujuan yang jelas memudahkan peneliti atau pembaca untuk meneliti masalah, sehingga dapat tercapai sesuai dengan apa yang diinginkan oleh penulis.

Adapun tujuan penelitian ini adalah adalah untuk mengetahui hubungan penguasaan unsur intrinsik cerpen dengan

kemampuan menulis cerpen oleh siswa kelas XI SMK Swasta Maju Binjai Tahun Pelajaran 2019/ 2020.

\subsection{Manfaat Penelitian}

Berdasarkan tujuan penelitian yang telah dirumuskan di atas, maka penelitian ini diharapkan bermanfaat sebagai :

1. Sebagai bahan masukan bagi penulis sebagai calon pendidik.

2. Untuk menambah wawasan siswa dalam teori sastra dan menulis cerpen.

3. Sebagai bahan masukan bagi sekolah yang peneliti lakukan untuk meningkatkan mutu pendidikan dan pengajaran di sekolah tersebut.

4. Sebagai bahan studi penelitian yang relevan dikemudian hari.

\section{Kajian Teoretis}

\subsection{Pengertian Penguasaan}

Dalam Kamus Besar Bahasa Indonesia mengartikan "Penguasaan adalah kesanggupan, kecakapan atau kekuatan".

Penguasaan itu sangat diperlukan dalam aktivitas sehari-hari, karena seluruh aktivitas menuntut kemampuan yang lebih dari apa yang dikerjakanya dan apa yang diharapkan dapat tercapai dengan baik. Dalam hal ini kemampuan menulis cerpen harus didasari kemampuan di bidang membaca, bakat dan minat. Mutu dari cerpen yang dihasilkan akan nampak lebih baik apabila seseorang memahami tentang teori sastra dan cara menulis cerpen yang baik dan benar.

\subsection{Hakikat Teori Sastra}

Teori sastra ialah cabang ilmu sastra yang mempelajari tentang prinsip-prinsip, hukum, kategori, kriteria karya sastra yang membedakannya dengan yang bukan sastra. Secara umum yang dimaksud dengan teori adalah suatu sistem ilmiah atau pengetahuan sistematik yang menerapkan pola pengaturan hubungan antara gejala-gejala yang diamati. Teori berisi konsep/ uraian tentang hukumhukum umum suatu objek ilmu pengetahuan dari suatu titik pandang tertentu. Suatu teori dapat dideduksi secara logis dan dicek kebenarannya (diverifikasi) atau dibantah kesahihannya pada objek atau gejala-gejala yang diamati tersebut. Kritik sastra juga bagian dari ilmu sastra. Istilah lain yang digunakan para pengkaji sastra ialah telaah sastra, kajian sastra, analisis sastra, dan penelitian sastra. Untuk membuat suatu kritik yang baik, diperlukan kemampuan mengapresiasi sastra, pengalaman yang banyak dalam menelaah, menganalisis, mengulas karya sastra, penguasaan dan pengalaman yang cukup dalam kehidupan yang bersifat nonliterer, serta tentunya penguasaan tentang teori sastra.

Pada hakikatnya, teori sastra membahas secara rinci aspek-aspek yang terdapat di dalam karya sastra baik konvensi bahasa yang meliputi makna, gaya, struktur, pilihan kata, maupun konvensi sastra yang meliputi tema, 
tokoh, penokohan, alur, latar, dan lainnya yang membangun keutuhan sebuah karya sastra.

\subsection{Hakikat Kemampuan Menulis}

\section{a. Pengertian Menulis}

Menulis merupakan salah satu keterampilan berbahasa. Hampir semua orang mengetahui apa itu menulis, bahkan dapat dikatakan bahwa menulis merupakan salah satu kegiatan yang bisa dikerjakan dalam kehidupan sehari-hari.

Kemampuan menulis merupakan perwujudan bentuk komunikasi secara tidak langsung, tidak langsung bertatap muka dengan orang lain. Menulis merupakan suatu kegiatan yang produktif dan ekspresif. Memang pada kenyataannya menulis merupakan keterampilan yang dapat dikatakan lebih sulit daripada keterampilan berbahasa yang lain, seperti menyimak, membaca dan berbicara. Dalam proses menulis, dituntut agar memperhatikan struktur yang berkaitan dengan unsur-unsur tulisan agar pembaca dapat memahami pesan yang ingin disampaikan oleh penulis. Oleh karena itu, penulis harus benar-benar menggunakan atau memakai struktur sebuah tulisan seperti kata, kalimat, paragraf, dan lainlain dengan baik.

Bloom dalam Ahmadi, menyatakan bahwa "tulisan atau karangan (komposisi tulis) termasuk dalam katagori sintesis yaitu sebagai suatu produksi komunikasi yang unik dimana penulis mencoba dan berupaya untuk menyampaikan gagasan, ide, dan atau perasaan kepada orang lain (pembaca)". Sedangkan menurut Nurchasanah \& Widodo, menulis adalah usaha untuk menuangkan ide,pikiran, perasaan, dan kemauan denagn wahana bahasa tulis.

Dengan demikian, menulis adalah produksi komunikasi yang unik dalam mengungkapkan gagasan, ide, dan atau perasaan kepada pembaca untuk dipahami dengan menggunakan wahana bahasa tulis. Menulis merupakan tindakan berkomunikasi. Hal tersebut sejalan dengan pendapat Morsey dalam Nurchasanah \&Widodo bahwa berkomunikasi pada dasarnya merupakan kegiatanmenyampaikan pesan-pesan kepada orang lain dengan menggunakan bahasa, begitu juga dengan menulis.

\section{b. Tujuan Menulis}

Menulis memiliki tujuan yang bermacam-macam, tergantung dari tujuan sipenulis ingin menulis sesuai yang dikehendaki. Menurut Resmini dan Juanda, tujuan penulisan sesuatu tulisan merangkumnya sebagai berikut :

1. Assigment purpose (tujuan penugasan)

Tujuan penugasan ini sebenarnya tidak mempunyai tujuan sama sekali. Penulis, menulis karena ditugaskan, bukan atas kemauan sendiri (misalnya para siswa diberi tugas merangkum buku, sekertaris ditugaskan membuat laporan).

2. Altruistic purpose (tujuan altruistik)

Penulis bertujuan untuk menyenangkan para pembaca, menghindarkankedukaan para pembaca, ingin menolong para pembaca menghargai persaan danpenalarannya, membuat hidup para pembaca lebih mudah dengan karyanya itu.

3. Persuasive purpose (tujuan persuasif)

Tulisan yang bertujuan meyakinkan para pembaca akan kebenaran gagasan yang diutarakan.

4. Informational purpose (tujuan informasional, tujuan penerangan)

Tulisan yang bertujuan memberi informasi atau keterangan/penerangan kepada para pembaca.

5. Self-expressive purpose (tujuan pernyataan diri) 
Tulisan yang bertujuan memperkenalkan atau menyatakan diri sang pengarang kepada pembaca.

6. Creative purpose (tujuan kreatif)

Tujuan ini erat berhubungan dengan tujuan perernyataan diri. Tulisan yang bertujuan mencapai nilai-nilai artistik, nilai-nilai kesenian.

7. Problem Solving purpose ( tujuan pemecahan masalah)

Tujuan ingin memecahkan masalah yang dihadapi, ingin menjelaskan,menjernihkan, serta menjelajahi dan meneliti secara cermat pikiran-pikiran dangagasannya sendiri agar dapat diterima oleh para pembaca.

Dari penjelasan di atas peneliti menyimpulkan bahwa tujuan dari pada menulis itu memiliki berbagai macam tujuan tergantung dari sisi penulis dan sisi pembaca menyikapi hal tersebut seperti di kemukakan di atas.

Berdasarkan batasan ini maka dapat dikatakan bahwa tujuan menulis adalah (1) tulisan yang bertujuan untuk memberitahukan atau mengajar disebut wacana informatif (informative discourse), (2) tulisan yang bertujuan untuk meyakinkan atau mendesak disebut wacana persuasif (persuasive discourse), (3) tulisan yang bertujuan untuk menghibur atau menyenangkan atau yang mengandung tujuan estetik disebut tulisan literer atau wacana kesastraan (literarydiscourse), (4) tulisan yang mengekspresikan perasaan dan emosi yang kuat atau berapi-api disebut wacana ekspresif (expressive discourse).

\section{c. Manfaat Menulis}

Menurut Akhadiah, menulis mempunyai manfaat sebagai berikut: Dengan menulis kita dapat lebih mengenali kemampuan dan potensi diri kita. Kita mengetahui sampai di mana pengetahuan kita tentang suatu topik. Untuk mengembangkan topik itu kita terpaksa berpikir, menggali pengetahuan dan pengalaman yang kadang tersimpan di alam bawah sadar.

1) Melalui kegiatan menulis kita dapat mengembangkan berbagai gagasan. Kita terpaksa bernalar menghubung-hubungkan serta membandingkan fakta-fakta yang mungkin tidak pernah kita lakukan jika kita tidak menulis.

2) Kegiatan menulis memaksa kita lebih banyak menyerap, mencari, serta menguasai informasi sehubungan dengan topik yang kita tulis. Dengan demikian kegiatan menulis memperluas wawasan baik secara teoretis maupun mengenai fakta-fakta yang berhubungan.

3) Menulis berarti mengorganisasikan gagasan secara sistematik serta mengungkapkannya secara tersurat. Dengan demikian, kita dapat menjelaskan permasalahan yang semula masih samar bagi diri kita sendiri.

4) Melalui tulisan kita akan dapat meninjau serta menilai gagasan kita sendiri secara lebih objektif.

5) Dengan menuliskan di atas kertas kita akan lebih mudah memecahkanpermasalahan, yaitu dengan menganalisisnya secara tersurat, dalam konteks yanglebih konkret.

6) Tugas menulis mengenai suatu topik mendorong kita belajar secara aktif. Kitaharus menjadi penemu sekaligus pemecah masalah, bukan sekedar menjadipenyadap informasi dari orang lain.

7) Kegiatan menulis yang terencana akan membiasakan kita berpikir sertaberbahasa secara tertib.

\section{d. Tahapan Dalam Proses Menulis}

Novi Resmini dan Dadan Juanda, menjelaskan proses menulis menjadi lima tahap yang didentifikasi melalui serangkaian penelitian tentang proses menulis sebagai berikut :

Tahap 1: Pramenulis. 
Pada tahap menulis siswa berusaha mengemukakan apa yang mereka tulis. Dalam hal ini guru bisa menggunakan strategi pramenulis yang diimplementasikan di kelas untuk membantu siswa memilih tema dan menentukan lancarnya proses menulis.

Tahap 2: Penyusunan Draft Tulisan (Drafting) Dalam proses menulis, siswa menulis dan menyaring tulisan mereka ke dalam konsep. Selama tahap penyusunan konsep, siswa terfokus dalam pengumpulan gagasan. Perlu disampaikan kepada siswa bahwa tahap ini mereka tidak perlu merasa takut melakukan kesalahan.

Tahap 3: Perbaikan (Revising)

Selama tahap perbaikan, penulis menyaring ide-ide dalam tulisan mereka. Siswa biasanya mengakhiri proses menulis begitu mereka mengakhiri dan melengkapi draft kasar, mereka percaya bahwa tulisan mereka telah lengkap.

Tahap 4: Penyuntingan (Editing)

Penyuntingan merupakan penyempurnaan tulisan sampai pada bentuk akhir. Sampai tahap ini, fokus utama proses menulis adalah pada isi tulisan siswa dengan fokus berganti pada kesalahan mekanik.

Tahap 5: Pemublikasian (Publishing)

Pada tahap akhir proses penulisan, siswa mempublikasikan tulisan mereka dan menyempurnakan dengan membaca pendapat dan komentar yang diberikan teman atau siswa lain, orang tua dan komunitas mereka sebagai penulis misalnya dapat dilakukan dengan kegiatan penugasan membacakan hasil tulisan di depan kelas

\subsection{Hakikat Cerpen}

\section{a. Pengertian Cerpen}

Cerpen sebagai salah satu genre sastra fiksi sangat menarik untuk ditulis dan dipelajari. Cerpen tergolong dalam cerita rekaan. Waluyo mengatakan bahwa istilah cerita rekaan terdapat kata 'cerita' dan 'rekaan' sebenarnya semua cerita mestinya adalah fiksi.
Namun akhir-akhir ini banyak juga cerita yang bukan fiksi karena perkataan cerita itu berubah makna meluas yakni mengisahkan juga yang bukan fiksi sehingga timbul cerita nonfiksi. Baik cerita fiksi maupun nonfiksi termasuk jenis prosa. Prosa ini pun sering kali diklasifikasikan menjadi prosa fiksi ( prose fiction) dan prosa nonfiksi (prosenonfiction). Kata fiksi berarti bahwa cerita itu merupakan hasil khayalan atau hasil imajinasi dan bukan cerita yang nyata terjadi.

Cerpen adalah cerita yang membatasi diri dalam membahas salah satu unsur fiksi dalam aspeknya yang terkecil. Kependekan cerita pendek bukan karena bentuknya yang jauh lebih pendek dari novel, tetapi aspek masalahnya yang sangat dibatasi. Untuk menjelaskan pengertian cerpen akan dikutip beberapa pendapat ahli sebagai berikut : Tarigan mengatakan bahwa : "Cerita pendek adalah penyajian suatu keadaan tersendiri atau suatu kelompok keadaan yang memberikan kesan yang tunggal pada jiwa pembaca. Cerita pendek tidak boleh dipenuhi dengan hal-hal yang tidak perlu". Selanjutnya Semi, berpendapat : "Cerita pendek adalah karakter yang dijabarkan lewat rentetan kejadian daripada kejadian-kejadian itu sendiri satu persatu. Apa yang terjadi di dalamnya lazim merupakan satu pengalaman atau penjelajahan".

Dari pendapat di atas jelaslah cerpen merupakan karya sastra yang memang pendek. Cerpen merupakan karya paling sederhana, isinya merupakan satu kebulatan ide atau ide tunggal, dan lebih mengutamakan kesingkatan, padat dan lengkap serta tingkat pada kesatuan jiwa.

\section{b. Unsur-Unsur Yang Membangun Sebuah Cerpen}

Penghargaan atau penilaian yang lazim disebut apresiasi cerpen dilakukan bila kita mengetahui unsur-unsur membangun cerpen 
tersebut. Bila kita mengapresiasi cerpen berarti kita membicarakan tentang unsur-unsur. Kenikmatan sebuah cerpen dapat kita temukan bila kita pahami tentang unsur-unsur yang membangun. Unsur-unsur yang membangun sebuah cerpen adalah sebagai berikut:

\section{Tema}

Tema adalah ide sebuah cerita. Sebuah karya sastra yang berbentuk cerpen harus ada temanya. Tema merupakan pokok permasalahan suatu karya sastra. Melalui tema pengarang memperhatikan ketimpangan yang terjadi di masyarakat.

Untuk memperjelas masalah tema ini, peneliti mengemukakan pendapat para ahli sastra.

"Suatu cerita haruslah mempunyai tema atau dasar yang merupakan tujuan penulis menuliskan watak dari para pelaku pada ceritanya dengan dasar tema tersebut. Dengan demikian tidaklah berlebih-lebihan kalau dikatakan bahwa tema atau dasr ini merupakan hal yang penting dalam sebuah cerita, suatu dasar yang tidak mempunyai tema tentu tidak ada gunanya dan artinya".

Jadi tema adalah suatu hal yang penting di adalam sebuah cerita. Sebuah cerita tanpa tema tentu saja tidak ada artinya, walaupun pengarang tidak menjelaskan temanya secara eksplisit hal ini disampaikan oleh pembaca setelah selesai membaca ceritanya.

\section{Tendens atau Amanat}

Tendens atau amanat merupakan unsur yang berhubungan dengan tema. Seorang penulis terlebih dahulu menetapkan tujuan tulisannya. Tendens yang disajikan dapat hanya tertulis secara inplisit. Tendens menyatu dengan tema dalam menyajikan sebuah tulisan. Dari tema seorang seorang penulis beranjak menentukan tendens dari cerita yang dibuatnya. 3. Peristiwa Cerita (Alur atau Plot)

Pada dasarnya seperti bentuk-bentuk cerita lainnya maka cerpen juga menceritakan sesuatu cerita atau keajaiban. Peristiwa itu disusun sedemikian rupa sehingga terciptalah suatu peristiwa yang logis. Dengan daya hayal dan imajinasinya pengarang mencoba menciptakan kondisi cerita menjadi sebab atau akibat kejadian lain. Rangkaian peristiwa atau kejadian yang disusun sedemikian rupa tersebut itulah yang dinamakan alur atau plot (peristiwa cerita).

Untuk memperjelas tentang pentingnya kedudukan plot atau alur ini, penulis akan mengutip pendapat beberapa ahli. Seperti pendapat Hudson yang dikutip Nugroho mengatakan bahwa : "Plot adalah rangkaian kejadian dan perbuatan". Pada umumnya alur cerpen terdiri dari :

a. Alur buka yaitu situasi yang mulai terbentang sebagai suatu kondisi permulaan yang akan dilanjutkan dengan kondisi berikutnya.

b. Alur tengah yaitu kondisi sudah mulai bergerak karena kondisi yang sudah mulai memuncak.

c. Alur puncak yaitu kondisi mencapai puncak klimaks peristiwa.

d. Alur tutup yaitu kondisi memuncak, sebelum mulai menampakkan pemecahan atau penyelesaian.

4. Tokoh Cerita atau Karakter

Sebuah cerita pendek sama denagn bentuk cerita fiksi yang lain harus didukung oleh pelaku. Penempatan pelaku yang ditata secara baik akan semakin menarik perhatian pembaca. Tokoh dalam sebuah cerita adalah satu hal yang penting. Seperti yang diungkapkan Semi berikut ini :

"Masalah penokohan dan perwatakan merupakan salah satu hal yang kehadirannya dalam sebuah cerpen amat penting dan bahkan amat menentukan karena tidak mungkin ada suatu karya cerita pendek tanpa ada tokoh yang bergerak yang akhirnya membentuk alur cerita".

Setiap pengarang menginginkan pembaca memahami tokoh-tokoh atau pewatakan tokoh yang ditampilkannya. Ada tiga macam cara 
pengarang untuk memperkenalkan tokoh dan perwatakan dalam cerpen.

1) Dengan cara analitik, yaitu secara langsung menyebutkan dengan terperinci bagaimana pengarang atau watak para tokoh. Pengarang langsung menyampaikan tentang watak atau karakter para tokoh.

2) Dengan dramatik, yaitu pengarang secara tidak langsung menggambarkan watak para pelakunya, melainkan dengan cara :

a. Melukiskan tempat atau lingkungan sang tokoh.

b. Menceritakan percakapan sang tokoh dengan tokoh lain.

c. Menceritakan perbuatan, tingkah laku atau reaksi tokoh terhadap suatu kejadian.

3) Dengan cara analitik dan dramatik, yaitu pengarang menggambarkan tokoh-

tokoh itu dengan berbagai cara seperti yang telah disebutkan tadi. Baik secara

langsung maupun tidak langsung.

5. Latar (Setting)

Latar berhubungan atau berkenaan dengan masalah terjadinya cerita, waktu terjadinya dan situasi penceritaan. Latar atau landas tumpu (setting) cerita adalah lingkungan tempat peristiwa terjadi. Untuk dapat melukiskan latar dengan tepat seorang pengarang haruslah mempunyai pengetahuan yang cukup tentang keadaan tempat dan waktu yang akan dijadikan latar peristiwa yang diceritakan.

Latar (setting) ini gunanya bukan saja memberikan gambaran dengan jelas tentang peristiwa yang terjadi, sering juga memberikan gambaran tentang watak pelaku. Sumardjo mengatakan : "Setting atau latar belakang bisa berarti banyak yaitu tempat tertentu akibat situasi lingkungan atau zamannya,cara hidup tertentu, cara berpikir tertentu".

Dari pendapat di atas, penulis menarik kesimpulan bahwa latar atau setting sangat penting artinya pada sebuah cerita pendek.

\section{Pusat Pengisahan (Point of View)}

Point of view atau pusat pengisahan sering juga disebut sebagai sudut pandang. Sudut pandang pengarang adalah posisi dan penempatan diri pengarang

dalam ceritanya, atau dari mana ia melihat peristiwa-peristiwa yang terdapat dalam cerita tersebut.

Rusyana mengatakan : "Point of view pada dasarnya adalah visi pengarang, atinya sudut pandang yang diambil pengarang untuk melihat kejadian suatu cerita".

Ada empat macam Point of view yang dipakai pengarang dalam cerpen, yaitu :

1) Pelaku sebagai orang pertama atau tokoh utama yaitu bercerita tentang keseluruhan kejadian atau peristiwa terutama yang menyangkut diri tokoh.

2) Pengarang sebagai tokoh bawahan, jadi pengarang yang menentukan cerita tokoh utama, dan pengarang terlibat pula dalam cerita itu.

3) Pengarang hanya sebagai pengamat yang berada di luar cerita.

4) Campuran, kadang-kadang pengarang hanya betindak sebagai pengamat tapi kadang-kadang berusaha juga menyelam ke dalam cerita.

\section{Gaya (Style)}

Gaya pengarang merupakan ciri khas seorang pengarang. Gaya dalam cerpen meliputi gaya dalam penulisan/pemaparan dan gaya penggunaan bahasa. Gaya dalam penulisan mempunyai hubungan yang erat dengan kebiasaan rasa indahnya pengarang. Gaya yang pertama ini berkenaan dengan darimana ia mulai menulis, dari awal hingga akhir mengikuti ukuran kronologis atau malah sebaliknya (flash back). Gaya kedua meliputi begaiman pemilihan kata (diksi), bagaimana pengungkapan dan gaya bahasa mana yang menonjoldalam cerpen itu. 
Berhasil tidaknya seorang pengarang cerpen justru tergantung dari kecakapannya mempergunakan gaya yang serasi dalam karyanya. Seperti yang dikatakan Sumardjo :

Gaya adalah cara khas pengungkapan seseorang. Cara bagaimana seseorang memilih tema persoalan, meninjau persoalan dan menceritakannya dalam sebuah cerpen, itulah gaya pengarang itu sendiri. Dengan kata lain gaya adalah pribadi pengarang itu sendiri. Dan sangat pribadi, ia berada secara khas di dunia ini”.

\section{c. Ciri-Ciri Cerpen}

Berbagai pendapat tentang pengertian cerita pendek. Pakar yang satu mengatakan cerita pendek adalah cerita yang dibuat secara singkat. Pakar lain mengatakan bahwa cerpen adalah cerita yang dibuat secara singkat dan sederhana dan dapat dibaca sekali duduk.

Henry GunturTarigan mengatakan ciriciri khas sebuah cerita pendek yaitu:

1. Singakat, padat dan intensif

2. Memiliki unsur utama yaitu adanya tokoh dan gerak

3. Tajam, sugestif dan menarik perhatian

4. Mengandung interpretasi pengarang tentang konsepsinya mengenai kehidupan (langsung/tidak langsung)

5. Menimbulkan satu efek dalam pikiran pembaca

6. Jalan cerita, pertama-tama menarik perasaan dan menarik pikiran

7. Mengandung detail-detail dan insideninsiden yang dipilih dan bisa menimbulkan pertanyaan-pertanyaan dalam pikiran membaca

8. Mengandung sebuah insiden yang menguasai jalan cerita Mempunyai seorang pelaku utama

9. Mempunyai kesan yang menarik

10. Cerpen tergantung pada situasi

11. Cerpen memberikan impresi tunggal

12. Cerpen memberikan suatu kebulatan efek

13. Cerpen menyajikan suatu emosi
14. Jumlah kata-kata terdapat dalam cerpen baisanya 10.000 kata atau 33 halaman kuarto.

\section{Metodelogi Penelitian}

\subsection{Metode Penelitian}

Dalam melakukan penelitian seseorang dapat melakukan berbagai macam metode. Namun metode yang dipakai hendaknya sesuai dengan tujuan penelitian yang dilakukan. Winarno Surakhmad mengatakan bahwa :

"Metode merupakan cara utama untuk mencapai suatu tujuan, misalnya untuk menguji suatu rangkaian hipotesa dengan menggunkana teknik serta alat-alat tertentu. Cara utama itu dipergunakan setelah menyelidiki, memperhitungkan kewajarannya ditinjau dari tujuan penyelidikan serta dari situasi penyelidikan".

Berdasarkan pendapat di atas, maka metode yang digunakan dalam penelitian ini adalah metode deskriptif korelasi. Pendekatan yang digunakan dalam penelitian ini adalah pendekatan kuantitatif. Sebagaimana yang dikemukakan oleh Nana Sudjana dan Ibrahim menjelaskan bahwa penelitian deskriptif korelasi adalah penelitian yang berusaha mendeskriptifka atau menggambarkan suatu hubungan gejala, peristiwa, kejadian yang terjadi pada saat sekarang.

Dalam hal ini metode tersebut bertujuan untuk menggambarkan hubungan penguasaan unsur intrinsik cerpen dengan kemampuan menulis cerpen siswa kelas XI SMK Swasta Maju Binjai tahun Pelajaran 2019/2020.

\subsection{Desain Penelitian}

Desain penelitian merupakan abstraksi dari fenomena-fenomena yang sedang diteliti dengan judul penelitian ini yaitu : Hubungan penguasaan unsur intrinsik cerpen dengan kemampuan menulis cerpen siswa kelas XI SMK Swasta Maju Binjai tahun Pelajaran 2019/2020. Desain penelitian yang sesuai 
dengan judul penelitian ini dapat digambarkan sebagai berikut :

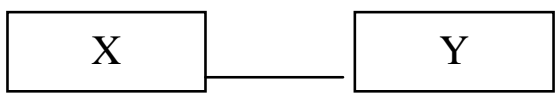

\section{Keterangan :}

$\mathrm{X}$ : Penguasaan unsur intrinsik cerpen

$\mathrm{Y}$ : Kemampuan menulis cerpen

: Hubungan variabel $\mathrm{X}$ dengan

variabel $\mathrm{Y}$

\subsection{Variabel Penelitian}

Variabel adalah istilah yang menunjang pada gejala, karakteristik, atau keadaan yang kemunculannya berbeda-beda pada setiap subjek seperti yang diungkapkan Sukardi, bahwa "variabel adalah objek penelitian, atau apa yang menjadi titik perhatian suatu penelitian".

Kemudian Sukardi juga menegaskan kembali bahwa " variabel dapat digolongkan menjadi dua macam yaitu variabel bebas dan variabel terikat".

Berdasarkan pendapat di atas, maka penelitian ini terdapat dua variabel yaitu variabel bebas dan terikat. Adapun yang menjadi variabel pada penelitian ini sebagai berikut:

1. Variabel bebas (variabel X) : Penguasaan Unsur Intrinsik Cerpen

2. Variabel terikat (variabel Y) : Kemampuan Menulis Cerpen

\subsection{Instrumen Penelitian}

Untuk memperoleh data empiris dari penelitian ini dilakukan pengembangan tes untuk mengukur kedua variabel tersebut. Pada variabel bebas atau variabel $\mathrm{x}$ yaitu penguasaan unsur intrinsik cerpen, peneliti menggunakan alat pengumpul data dengan menggunakan tes objektif pilihan berganda yang terdiri dari 15 butir soal. Setiap butir soal pilihan berganda terdiri dari empat pilihan jawaban dengan satu jawaban yang benar. Selanjutnya untuk mengukur jawaban yang benar dari bentuk tes itu diberi skor 1 (satu) dan jawaban yang salah diberi skor 0 (nol).

Sedangkan untuk variabel terikat atau variabel y yaitu kemampuan menulis cerpen, penulis menggunakan tes uraian. Dalam tes ini siswa disuruh menulis sebuah cerpen. Tema cerpen yang akan ditulis adalah tentang kejujuran.

\subsection{Teknik Analisis Data}

Untuk memperoleh data penguasaan unsur intrinsik cerpen dengan kemampuan menulis cerpen, maka digunakan teknik analisis kuantitatif. Sebagaimana yang dikatakan Ali :

"Teknik analisis kuantitatif disebut juga dengan teknik statistik dan digunakan untuk mengolah data yang berbentuk angka, baik hasil pengukuran maupun hasil mengubah data kualitatif. Teknik ini sangat banyak digunakan dalam berbagai kegiatan penelitian, oleh sebab itu dianggap lebih mudah, namun dapat menghasilkan kesimpulan yang lebih tepat dibandingkan dengan kualitatif".

Adapun langkah-langkah yang di lakukan untuk mendapatkan data adalah sebagai berikut

1. Menghitung skor dari penguasaan unsur intrinsik (variabel $\mathrm{X}$ ) yang diperoleh siswa dan mengubahnya menjadi nilai akhir. Dengan menggunakan rumus :

Nilai Akhir $=\frac{\text { skor } \text { yang diperoleh }}{\text { jumlah } \text { soal }} \times 100$

2. Menghitung skor kemampuan menulis cerpen (variabel $\mathrm{Y}$ ) yang diperoleh dari setiap siswa dan mengubahnya menjadi nilai akhir dengan menggunakan rumus sebagai berikut : $\frac{\text { skor yang diperoleh }}{\text { skormaksimal }} \times 100$

3. Mencari rata-rata (mean) kedua variabel Dengan rumus

$$
M=\frac{\text { Total_Niliai_Akhir }}{\text { Jumlah_Siswa }}
$$


Kemudian pengolahan kedua tes diatas , diklsifikasikan dengan skala nominal yang dinyatakan sesuai dengan pendapat Arikunto :

- Kemampuan sangat baik bila nilai 90-100

- Kemampuan baik bila nilai 70-80

- Kemampuan sedang bila nilai 60

- Kemapuan kurang bila nilai 50

- Kemampuan sangat kurang nilai 40 atau lebih kecil.

4. Mencari hubungan antara penguasaan unsun intrinsik cerpen dengan kemampuan menulis cerpen dengan menggunakan rumus korelasi product moment :

$$
\mathrm{r}_{\mathrm{y}}=\frac{N \sum X Y-\left(\sum X\right)\left(\sum Y\right)}{\sqrt{\left.\left(N \sum X^{2}\right)-\left(\sum X\right)^{2} \mid\left(N \sum Y^{2}\right)-\left(\sum Y\right)^{2}\right]}}
$$

Keterangan :

$$
\begin{aligned}
& \mathrm{r}_{\mathrm{xy}}=\text { Koefisien korelasi antar } \mathrm{X} \text { dan } \mathrm{Y} \\
& \mathrm{N}
\end{aligned}
$$

$\mathrm{X}=$ Jumlah skor $\mathrm{X}$ yang di kuadratkan

$\mathrm{Y}$ = Jumlah skor $\mathrm{Y}$ yang dikuadratkan

$\mathrm{Xy}=$ Jumlah perkalian skor $\mathrm{X}$ dengan skor

Selanjutnya setelah didapat angka koefisien $r$ kemudian diinterpretasikan dengan nilai $r$ yang terdapat pada tabel nilai-nilai $r$ seperti pada buku statistik. Adapun tingkattingkat korelasi antara penguasaan unsur intrinsik cerpen dengan kemampuan menulis cerpen yang ingin penulis teliti adalah dalam taraf signifikan 5\%.

Winarno Surakhmad mengatakan bahwa :

"Pada umumnya yang dipakai sebagai signifikansi adalah 5\% atau $1 \%$ (atau 0,5 atau $0,1)$. Sekiranya telah ditetapkan taraf signifikansi 0,5 untuk mengetes suatu hipotesa, maka kemungkinan kita akan menolak hipotesa yang benar adalah 5 diantara 100 atau dengan kata lain percaya bahwa 95\% dari keputusan itu ialah benar".

\section{DAFTAR PUSTAKA}

Ahmadi,Mukhsin. 2008. Materi Dasar Pengajaran Komposisi Bahasa Indonesia. Jakarta : Dirjen P2LPTK

Ali, Muhammad. 2001. Penelitian Kependidikan Prosedur dan Strategi. Bandung: Angkasa

Arikunto, Suharsimi. 2004. Prosedur Penelitian Suatu Pendekatan Praktik. Jakarta : Rineka Cipta

Departemen Pendidikan dan Kebudayaan. 2004. Kamus Besar Bahasa Indonesia. Jakarta : Balai Pustaka

Koentjaraningrat. 2001. Metode-Metode Penelitian Masyarakat. Jakarta : Gramedia

Nugroho, Notosusanto. 1998. Prinsip Dasra Sastra. Bandung : Angkasa

Resmini, Novi dan Juanda, Dadan. 2008. Pendidikan Bahasa dan Sastra Indonesia di Kelas Tinggi. Bandung : UPI Press

Semi, M Atar. 1999. Rancangan Pengajaran Bahasa dan Sastra. Bandung : Angkasa

Sumarjo, Jakob. 2005. Apresiasi Sastra Indonesia. Jakarta : Gramedia

Surakhmad, Winarno. 2002. Pengantar Penelitian Ilmiah dasar Metode dan Teknik. Bandung : Tarsito

Sugiyono. 2008. Metode Penelitian Pendidikan. Jakarta: Alfabeta

Suryabrata, Sumardi. 2009. Metode Penelitian. Jakarta: Rajawali Pers

Sukardi. 2009. Metodologi Penelitian Pendidikan. Yogyakarta: Bumi Aksara 
Syamsuri dan Rusyana. 2002. Pedoman Penelitian Bahasa Indonesia. Jakarta : Pusat Bahasa

Tarigan, Henry Guntur. 2003. Sekelumit Catatan Mengenai Apresiasi Sastra. Bandung : FKSS

Widodo \& Nurchasanah. 2003. Keterampilan Menulis dan Pengajarannya Malang : FS UM
Waluyo, H.J. 2001. Apresiasi dan Pengkajian Prosa Fiksi . Salatiga: Widya Sari Pers

http://pemberianalam.blogspot.com/2012/03/pe ngertian-teori-sastra-kritik-sastra.html?. Terakhir diakses Tanggal 15 Mei 2014 